\title{
'Blue in the Face' Filmi ve Modernizm: Kentlilik ve Aidiyet Üzerinden Bir Değerlendirme
}

\author{
'Blue In The Face' and Modernism: An Assessment within The Context \\ of Urbanity and Belongingness
}

\section{Serdar ÖZTÜRK* FIrat OSMANOĞULLARI**}

\begin{abstract}
Öz: Blue in the Face (Paul Auster, Wayne Wang, Harvey Wang, 1995) her türden farklı insanların bir arada yaşadığı Brooklyn'de kolektif kimlikleri, aidiyetleri ve onların teknolojik kaba bir determinizm etrafındaki modernleşme anlayışına karşı sosyalleşme üzerinden geliştirdikleri direnme mekanizmalarını anlatan bir filmdir. Film bir kenti evi gibi hissetmenin ne demek olduğunu, Brooklyn ve sakinlerini temel alarak modernist bir yaklaşımla ve eğlenceli bir dille anlatır. Bu çalışma kentsel dönüşüm projelerinin büyüsü altında sosyalleşmenin ve insanlar arasındaki iletişimin giderek kaybolmasının ne anlama geldiğini bu film örneğinde analiz etmektedir. Yaşam alanlarına sahip çıkarken tüm farklılıklarla kolektif bir kimlik inşasının kent kimliği altında nasıl mümkün olabileceğine dair düşünmemize olanak veren film, bu yönüyle günümüzde halen güncelliğini ve önemini korumaktadır.
\end{abstract}

Anahtar sözcükler: Blue in the Face, Kentlilik, Aidiyet, Modernizm

Abstract: Blue In The Face (Paul Auster, Wayne Wang, Harvey Wang, 1995) is a movie which tells the story of collective identities, belongingness and, by setting up socialisation, the struggle of people living in Brooklyn under tough and strict determinist modernisation. The movie, through using a modernist approach and humour in filmic images and focusing upon Brooklyn and its inhabitants, shows the meaning of living in a city like our home. This study, by using this movie, analyses the significance of gradually disappearing socialisation and communication amongst people. The movie makes us reflect upon how to construct a collective identity with all the differences through appropriating life worlds, and with this dimension, remains up-to-date.

Keywords: Blue in the Face, Urbanity, Belongingness, Modernism

Neden bir kent bir filme konu olabilmekte? Blue in the Face (1995) filmi bu sorunun cevabina dair birçok şey söylüyor [Film aslında Wayne Wang ve Paul Auster tarafindan aynı ekiple, büyük ölçüde aynı mekânda ve aynı yıl çekilen Smoke filminden sonra arda kalan makaralarla çok kısa sürede ve büyük bir çoğunluğu da doğaçlama olarak çekilmiştir. Zaten "Blue in the Face" deyimi de İngilizcede "nefessiz kalmış, yüzü mosmor olmuş" kişiler için kullanılmaktadır ve filmde o kadar çok doğaçlama diyalog vardır ki, bu anlamda deyim, konuşmaktan nefessiz kalmış oyuncular kastedilerek, filme ismini vermiştir]. Blue in the Face gibi, sinema tarihi

\footnotetext{
* Prof. Dr., Gazi Üniversitesi, İletişim Fakültesi, Radyo, TV, Sinema Bölümü, Ankara. iletişim2008@gmail.com

** Doktora Öğrencisi, Gazi Üniversitesi, İletişim Fak., Radyo, TV, Sinema Bölümü, Ankara. firatosmanogullari@gmail.com Film Türkiye'de 'Karanlık Sokaklar' adıyla gösterilmiş olup, isminin Türkçe karşıllı̆ı düşünüldüğünde bu çalışmada Türkiye’de gösterildiği adıyla değil, orijinal ismiyle kullanılması tercih edilmiştir.
} 
boyunca birçok şehir hatırı sayılır miktarda filmde başrolde yer almıştır. Örneğin, Walter Ruttmann, Kraucer'in de belirttiği gibi, Sovyet montajından, özellikle de Dziga Vertov ve onun "Kino-eye" (sinema-göz) grubundan etkilenerek çektiği Berlin: Bir Kent Senfonisi (Berlin: Die Sinfonie der Grosstadt, 1927) adlı filmde Berlin'i merkeze almış, ilkbaharın sonunda şehrin bir gününü anlatmıştır (Kraucer 2011, 179-181). Aynı şehir, bu sefer Roberto Rossellini'nin Almanya, Sıfır Yılı (Germania Anno Zero 1948) filminde II. Dünya Savaşı sonrasında yıkılmış, harabe olmuş bir şehir olarak seyirci karşısına çıkar. Wim Wenders de yine Berlin'in merkezde yer aldığı Berlin Üzerinde Gökyüzü (Der Himmel Über Berlin 1987) filmi ile birlikte Lizbon Hikayesi (Lisbon Story 1994) ve Palermo'da Yüzleşme (Palermo Shooting 2008) gibi filmlere imza atmıştır ve filmlerdeki esas öğe filmlerin adlarından da anlaşılacağı üzere şehirlerdir. Çeşitli yönetmenlerin çektikleri kısa filmlerden oluşan Paris, Seni Seviyorum (Paris, je'taime 2006), Woody Allen'in çektiği Paris'te Bir Gece Yarısı (Midnight in Paris, 2011) gibi filmlerde de en önemli rol kuşkusuz Paris'indir. İstanbul da birçok filme konu olmuştur. Fatih Akın'ın İstanbul Hatırası: Köprüyü Geçmek (Crossing the Bridge: The Sound of İstanbul, 2005) filmi, çeşitli yönetmenlerin çektikleri kısa filmlerden oluşan Anlat İstanbul (2004) gibi filmlerde İstanbul popüler veya alternatif müzisyenleri, arka sokakları, karanlık dehlizleri, suçluları gibi birçok yönü ile seyircinin karşısına çıkmıştır. Kraucer 1930 yılında yazdığı bir makalede Rene Clair'in Paris Damları Altında (Sous les toits de Paris 1930) filminde kentin rolünü vurgulamak için şu ifadeleri kullanmaktadır: "Gündelik yaşam sadece bir arka plan ya da dolgu malzemesinden daha fazladır, öykünün asıl itici gücünü oluşturur". Daha sonra şöyle devam eder: “Öykü Paris'te geçmiyor da Paris'in kendisi bu öyküyü oynuyor” (Kraucer 2008, 48). Bütün bu filmlerin ve adı burada geçmeyen daha birçok filmin merkezinde asıl bir anlatı olsa da, kent asli bir figür olarak hep mevcuttur. Bütün bu örneklerden anlaşllan o ki, bir kentin filme konu edilmesi insanların yaşam alanlarıyla yüzleşmesi ve tüm çelişkili yönleriyle birlikte yaşadıkları kenti kendilerinin kılabilmesi ile ilgilidir. Başka bir deyişle, 'bu kenti seviyorum' demenin ve dedirtmenin bir biçimidir.

Peki, kent figürü hangi özellikleri ile bir sinema filminde yer almaktadır? Bir yandan devasa gökdelenleri, büyük iş merkezleri ve alış veriş merkezleri ile karşımıza çıksa da, diğer yandan bir kenti ilgi çekici kılanın - şimdilik kuramdan bağımsız ifade etmek gerekirse - daha çok onun tarihsel önemi, buna bağlı olarak tarihsel dokusu, mimarisi, doğal güzellikleri ve onu özgün kılan her şey olduğunu söylemek mümkündür. Bununla birlikte, bir kentin aynı anda içinde barındırdığı uyum, çelişki ve çeşitlilik gibi unsurlar, Blue in the Face filminde olduğu gibi onu bir filmin merkezine koymaya yeter.

İnsanların yaşadıkları kenti kendilerinin kılabilmeleri, 'bu kenti seviyorum' diyebilmeleri bir kentten beklentileri ile doğrudan ilişkilidir. Bir insanın bir kentten beklentisi ne olabilir? Bu soruya çeşitli cevaplar vermek mümkün. Öncelikle kendisinin ve ailesinin temel ihtiyaçlarını karşılayabileceği bir iş alanı, barınma gibi yaşamın devamlılı̆̆ını sağlayacak zorunluluklar olduğu söylenebilir. Asıl cevaplar işte bu zorunlu ihtiyaçlar karşılandıktan sonra farklılaşacaktır. Eğlence, alış veriş, entelektüel faaliyetler gibi olguların yanında, bir bireyin sınıfsal kimliğinin dışında sahip olduğu ulusal ve dinsel kimliğinin, bu kimlik ile bağlantılı olan kültürel ve ahlaki normlarının gerektirdiği biçimde rahatça yaşama ihtiyacı ve hakkı da vardır. Bu kimliklerin bütününe her ne kadar toplumsal bir anlayıştan doğsalar da "bireysel kimlik" adını vermek mümkündür. Bazı kentlerde bu bireysel kimlikler bir homojenlik içerse de bazılarında oldukça farklılaşmaktadır. Dünyanın birçok kentinde farklılaşmış unsurların bir arada var olması oldukça sorunlu bir durum teşkil etmektedir. Egemen kodlara sahip olanların, farklı olanlara tahammülü bazı bölgelerde mümkün olmamakta ve saldırgan bir tutum içermektedir. Irkçılık tarihsel süreçte kendine farklı hedefler seçerek ortaya çıkmaktadır. Irkçılık siyahlara yönelik 
hareketlerden, işçi sınıfına, kadınlara, Yahudilere kadar genişlerken günümüzde daha çok göçmen işçilere ve azınlıklara karşı sürdürülmektedir. Taş'ın belirttiği üzere, Avrupa tarihinde ırkçılığın iki önemli işlevi vardır. İlk olarak sömürge imparatorluklarının gücünü artırmış diğer bir açıdan da 19. ve 20. yüzyıl Avrupa ülkelerinin ulusallaşmasına yardımcı olmuştur. Avrupa ülkeleri, acımaz bir devlet terörüyle farklı dili ve kültürü olan yerel bölgeleri tek bir merkeze, egemen bir dil ve kültüre bağlamaya çalışmışlardır (Taş 1999, 36-38). Avrupa'da 1rkçı saldırıların toplumsal nedenlerinden biri olarak göçmenlerin niceliksel artışını gösterilmiştir. Taş, Avrupa'nın çeşitli ülkelerinden örnekler vererek, bazı Avrupalıların 1rkçı saldırılarla göçmen sayısı arasında doğrudan bir bağlantı kurduğunu ileri sürmüştür. Bundan başka Taş, ikincil sebep olarak ırkçı şiddet ile ekonomik kriz arasındaki bağlantıya dikkat çekmiştir. Buna göre aşırı sağ şiddet, ekonomik kriz koşullarında ülke kaynaklarını yabancılarla bölüşmek istemeyenlerin başvurduğu bir yoldur. Son olarak Taş, üçüncü sebep olarak 1rkç1 şiddetin o ulusun kendi özelliklerinden kaynaklandığı ve o ulusa içkin olduğu bazı durumlar olabileceğini söylemektedir (Taş 1999, 93-94). Belçikalı Dardenne kardeşlerin filmlerinde, özellikle de Söz (La Promesse 1996) ve Rosetta (1999) gibi işsizlik, ırkçılık ve göçmenlik olgularını yoğun olarak işledikleri filmlerde bu durum görülmektedir.

Blue in the Face filminde ise bu türden farklılıkların bir arada yaşayabildiği bir kent olarak Brooklyn ana eksendedir. Şehirde çok farklı coğrafyalardan gelen oldukça büyük bir göçmen kitlesi olmasına rağmen, filmdeki insanlarda herhangi bir ırkçı tutum görülmez. Bu çalışmanın sonraki bölümlerinde görüleceği gibi, mümkün olduğunca bu kentteki farklılıkların bir aradalığına vurgu yapan fillm, Brooklyn'de yaşayanların kendi geleneklerini, bireysel kimliklerini rahatça sürdürebilirken, aynı zamanda da "taraftarlık" gibi birleştirici öğelerden bütünsel bir "kolektif kimlik" yaratmasının altını çizer. Bu kolektif kimlik, içinde "modernist" unsurlar barındıran, yaşadıkları şehrin kentsel dönüşüm projelerine kurban edilmemesi gerektiğini düşünen ve buna direnmeye çalışan çok çeşitli bireysel kimliklere sahip insanların, "ortak düşmana yönelik" beraber yarattıkları bir kimliktir. İşte bir kente ait olmak, bireysel ve toplumsal hayatın çelişkilerine maruz kalan bireyin, tüm bunlara rağmen kendini evinde hissedebilme arzusuve bu arzudan kaynaklanan bir mücadele içerisinde olması ile alakalıdır. Blue in the Face filmi Brooklyn ve sakinlerini temel alarak modern bir yaklaşımla ve eğlenceli bir dille bunu anlatır. Bu çalışmada da özellikle Marshall Berman'ın 'modernizm' görüşü ekseninde Blue in the Face filmindeki kentlilik ve aidiyete dair unsurların nasil modernizm ile ilişkilendirilebileceği ele alınacaktır. Dolayısıyla çalışma, her ne kadar imajlardan yola çıkarak işlese de, kendisini bir film sosyolojisi çerçevesinde konumlandırmaktadır.

\section{Kentlilik, Modernizm ve Bir Tehdit Olarak Kentsel Dönüşüm Projeleri}

"Nasıl bir dünyada yerleşiğiz? Çelişkiler, çoklu konumsallıklarla, farklı eylem alanlarına tercüme olan zorunlu hayali kaçışlarla, eşitsiz coğrafi gelişmelerle ve çok tartışmalı anlam ve emellerle dolu oldugunu biliyoruz. Dünyanin koskocaman ve inanilmaz derecede karmaşık olmast, eleştirelliğe ve bireysel ve kolektif iradelerin kisitl özgürlük içinde iflasına bolca olanak tanır. Ancak, görünür tercih miktarlnın muazzamliğ ve mücadelelerin sürdürülebileceği alanların farklılı̆̆ı sürekli olarak güçsüzleştirici bir kafa karışıklığı yaratma tehlikesi barındırır (örneğin küreselleşmenin etkili bir biçimde yarattığ 1 gibi). Dahası, ne kadar iyi düşünülmüs olursa olsunlar, eylemlerimizin beklenmeyen sonuçlar doğurmasını önlemek imkânsı gibi görünüyor. Bir taraftan bizi çevreleyen kisitların gücünü kabullenirken, bu tür kart- 
şlklıklar arasından nasıl önümüzü görüp de olanaklara dair farklı bir görüş üreteceğiz?” (Harvey 2011, 286).

David Harvey, yukarıdaki paragrafta içinde yaşanılan dünyanın bireysel iradeyi aşan karmaşık yapısına dikkat çekerken, bu yapının içinde nasıl olur da insanların alternatif yaşam biçimlerini oluşturmaya yönelik bir mücadele içinde olabileceklerini sorgulamaktadır. Burada ilk akla gelen soru, insanların yaşadıkları kentleri kendilerinin kılabilmek adına bu mücadelenin neye, kime karş1 yürütüleceğidir. Harvey başka bir eserinde, kapitalizm ve kentleşme arasındaki içsel ilişkinin varlığını şu sözleriyle ortaya koyar: "Kapitalizm mütemadi olarak ürettiği artı ürünün soğrulmast için şehirleşmeye ihtiyaç duyar" (Harvey 2013, 45). Demek ki kapitalizm kentleşmeye kentte yaşayanların rızası olmadan ve onlara rağmen ihtiyaç duyar. Demek ki insanların yaşadıkları kentleri kendilerinin kılmak adına mücadele etmeleri gereken her ne ise o kapitalizm ile alakalıdır. Peki, bu durumda kentlilerin kentleşmeye karşı olması gerektiği mi savunulmalıdır? Elbette hayır. Mücadelenin kendisi tam da bu çelişkide yatmaktadır: kentlilerin ortak yararını gözeten alternatif bir kentleşme biçimi. Birey yaşadığı kenti arzuladığı bir biçimde kurma ve yeniden kurma hakkına sahip olmalıdır. Bu noktada Lefebvre'nin yaptığı bir ayrıma kısaca değinmekte fayda vardır. Lefebvre (2013) şehir ile kent arasında bir ayrım olduğunu vurgular. Ona göre toplum bir bütün halinde kentleşmektedir. Bu kentleşme şehri yıkarak işlemekte, dolayısıyla bir oluş haline işaret etmektedir. Bu değişim karşısında pasif kalınması durumunda şu an için bir 'muhtemel nesne' olan kent bir süre sonra oluşumunu tamamlayacaktır. Lefebvre'e göre şehir sanayileşmeden önce de vardı. Kentten ise, ancak sanayileşmeden sonra söz edebilmek mümkün hale geldi. Şehir ona göre bir 'yapıt'tı ve kullanım değeri ile ilgiliydi. Kent ise bir 'ürün'dür ve dolayısıyla değişim değeri ile ilgilidir (Lefebvre 2016, 21-22). İşte kentleşmenin şehri yıkarak işlemesi ve bir oluş olması düşüncesi kullanım değerinden değişim değerine, yapıttan ürüne bir geçiş halinin yansımasıdır. Lefebvre'nin anahtar kavramlarından olan 'şehir hakkı' tam da değişim değerinin karşısına kullanım değerinin konulmasına gönderme yapar (Bu çalışmanın odaklandığı esas mesele Berman'ın ele aldığı şekliyle modernizm meselesi olduğundan, şehir hakkı kavramı uzun uzadıya tartışılmamıştır). Buradan hareketle Harvey şehir hakkı üzerine şunları söyler:

"Şehir hakkı, şehrin barındırdı̆̆ı kaynaklara bireysel veya kolektif
erişim hakkından çok öte bir şeydir. Şehri gönlümüze göre değiştirme
ve yeniden icat etme hakkıdır bu. Dahası, bireysel değil kolektif bir
haktır, çünkü şehri yeniden icat etmek kaçınılmaz olarak kentleşme
süreçleri üzerinde kolektif bir gücün uygulanmasına bağlıdır.
Kendimizi ve şehirlerimizi şekillendirmek ve yeniden şekillendirmek,
insan hakları için en değerli, fakat bir o kadar da ihmal edilmiş
olanıdır" (Harvey 2013, 44).

Kapitalist kentleşme ile insanların kendi arzuladıkları kentleşme, yani şehir hakkı arasındaki bu karşıtlık aynı zamanda bize bu iki bloğun farklı modernleşme anlayışları olduğuna da işaret etmektedir. Marshall Berman (2014) bunlardan ilkini mekanik modernleşme olarak ifade ederken, ikincisini ise diyalektik modernleşme olarak ifade eder.

Modernleşme terimi çoğunlukla sanayileşmede temellenmiş toplumsal gelişim evrelerine işaret etmek için kullanılmıştır (Sarup 2004, 187). Bu bağlamda modernizm üzerine, özellikle kapitalizmin ortaya çıkışından itibaren daha çok mekanik bir açıklama yapılmıştır. Bu açıklama eski olan her şeyi modernizm karşıtı olarak görür ve sürekli bir yenilik adına insan faktörünü göz ardı etme eğilimi gösterir, yani insana dışsaldır. Lefebvre'nin de Harvey'in de kentleşme eleştirisi, tam da bu modernizm anlayışının eleştirisidir. Bu modernizm anlayışı insanı şeyleşti- 
rir, yarattığı yenilikler ile onun, bu yeniliklerin sahte büyüsüne kapılıp tüketim nesneleri ile olan bağlarını güçlendirmeyi amaçlayarak daha fazla tüketime yönlendirir. Tek taraflı yani yukarıdan aşağıya gelişen bu süreç insanı ve dünyasını sürekli bir çözülmeye uğratır, onu sersemleştirir. Tüm sabit ilişkiler, eskiden saygıdeğer olan düşünceler ve görüşlerle birlikte çözülmektedir. Yeni oluşan ilişkiler ise daha kemikleşemeden miadını doldurmakta, "katı olan her şey buharlaşmakta", kutsal olan her şey dünyevileşmektedir. Böylece insanlar yaşam koşullarına ve karşılıklı ilişkilerine ayık kafayla bakmak zorunda kalmaktadır. İşte bu çelişkili durum, tek taraflı mekanik modernizm anlayışının ötesinde daha kapsamlı bir tanımlamayı zorunlu kılar. Yani bir taraftan mevcut yaşam koşullarında ve ilişkilerinde insanın kendisine bir yer açıp hayata devam etmesini, bir taraftan da bu koşulları ve ilişkileri sorguladığı ve bunları iyileştirmek üzere giriştiği mücadeleleri de kapsayan bir tanımı. Marshall Berman bu tanımı şöyle yapar:

“Modern olmak, kişisel ve toplumsal yaşamı bir girdap deneyimi gibi
yaşamak; insanın kendini ve dünyasını sürekli bir çözü̈lüs, yenileme,
sıkıntı, kaygı, belirsizlik ve çelişki içinde bulması demektir. Kısaca
katı olan her şeyin ergiyip havaya karıştı̆̆ bir evrenin parçaları
olmak... Öte yandan bir modernist olmak, insanın kendini bu girdabın
içinde bile bir şekilde evinde hissetmeyi başarması, bu girdabın
ritimlerini özümsemesi; bu girdabın akıntıları arasında, mahvedici
akışının ortaya çıkmasına izin verdiği gerçeklik, güzellik, özgürlük ve
adalet biçimleri arayışııda olmak demektir” (Berman 2011, 460).

İşte bu tanım modernizmin diyalektik tanımıdır, yani kapitalizmin çelişkilerini içinde barındıran bir tanımdır. "Modernleşme, geçmişten günümüze doğru akan karmaşık bir değişim sürecidir" (Loo \& Reijen 2006, 247). İnsanlar böylece maddi ilişkiler ağında kendi varlıklarını sürdürmekle beraber, somut ve bireysel etkinliklerini ise bu maddi ilişkileri iyileştirmek ve özgürleştirmek adına kullandıkları ölçüde modernisttirler.

Mekanik modernizm kendisini daha çok kentsel dönüşüm projelerinde göstermektedir. $\mathrm{Bu}$ projeler ise insanların olağan yaşamları için bir tehdit unsuru olmakla beraber görece iktidarın denetiminden uzak iletişim mekânlarını da yok etmektedir. Hal böyle olunca da insanlar kamusal anlamda bir diyalog geliştirme imkânı buldukları bu mekânları kendileri adına sahiplenme ve koruma eğilimi göstermektedirler. Eski olanı yok etmeye dayalı mekanik modernleşme cadde, sokak, meyhane, kahvehane gibi iletişim mekânlarının, yani, insanların kendilerini ve dünyalarını sürekli bir çözülüş, yenileme, sıkıntı, kaygı, belirsizlik ve çelişki içinde buldukları bir sistemden bir ölçüde kurtulabildikleri, kendilerini evlerinde hissedebildikleri mekânları tehdit etmektedir. Buralar insanların kendi etkinliklerini, potansiyellerini gerçekleştirebildikleri, kendilerini rahat hissettikleri yerlerdir, onların "modernist karşılaşmalar" yapabildikleri yegâne yerlerdir. İşte mekanik modernizmin yaptığı da bu modernist karşılaşmaları mümkün olduğunca azaltmaktır. Böylece insanların tüm etnik, sınıfsal, cinsiyete dayalı farklılıklarına rağmen bir araya gelebildikleri ve gerçeklik, güzellik, özgürlük ve adalet biçimleri arayışının mümkün olabileceği iletişim mekânları mekanik modernleşmenin hedefi haline gelmektedir. Berman bu husus hakkında şöyle der: "Çağdaş akım denilen şey, milyarlarca dolara patlayan "kent yenileme" projelerini esinledi. Ancak bunun sonucu, modern değerlerin yaşama geçirebileceği tek çevreyi yok etmek oldu... İlk bakuşta ne denli paradoks gibi görünse de... Kent yaşamında modernlik uğruna yapılması gereken, eskiyi korumak ve yeniye direnmektir" (Berman 2011, 422). Berman burada "paradoks" kelimesini kullanır; çünkü kentsel dönüşüm meseleleri söz konusu olduğunda yeniye karşı direnip eskiyi korumak mekanik 
modernleşme anlayışına göre modernizm karşıtıdır. Fakat diyalektik bir modernleşme anlay1şında ise, modernizmin kendisidir. $\mathrm{Bu}$ anlamda var olan yaşam alanlarının kent yenileme projelerine karşı savunulması, daha iyi bir dünyanın varlığını mümkün kılan dinamiklerin geliştirilmesini ortaya çıkarabilecek ortamı savunmak demektir. Buna karşın yukarıdan aşağıya doğru bir modernleşme anlayışını temsil eden kent yenileme projeleri ise mevcut sistemin devamlılığının üretilmesine ve yeniden üretilmesine hizmet eder. David Harvey ise şu ifadeleri kullanır:

“Toplumsal değişim kişisel olanla başlayıp bitse de, kişisel irade
beyanları veya bireyselleşmiş kişisel gelişimden (...) çok daha fazlası
söz konusudur burada. Haussmann, Robert Moses (Robert Moses adı
filmde de karşımıza çımaktadır ve ilerleyen bölümlerde adı geçecek-
tir) veya Oscar Niemeyer gibi karizmatik ve her şeye muktedir bir
insanın, başkaların yoğurarak kendi tikel ve kişisel vizyonuna ve
arzularına uydurmak amacıyla dünyalar inşa ettiği sanılsa da, salt
kişisel vizyondan çok daha fazlası vardır işin içinde. Sinıf çıarlarl,
siyasal iktidar, baskıcı güçlerin harekete geçirilmesi, söylemlerin ve
kamuoyunun biçimlendirilmesi ve benzeri faaliyetler de söz konusu-
dur” (Harvey 2011, 288-289).

Demek ki modernlik adına uygulanan kentsel dönüşüm projeleri kapitalist çıkarları gözetmekte (ki kapitalizm ve kentleşme arasındaki bağına daha önce değinilmişti), bu durum proje mimarları ve iktidar bloğu ile kol kola sürdürülmektedir.

\section{Modernizm ve Brooklyn Kentinin Sakinleri}

Auggie 14 yıldır Brooklyn'de Brooklyn Puro Şirketi adında bir tütün dükkânı işletmektedir. Dükkânın sahibi Vinny de aynı zamanda Auggie'nin arkadaşıdır. Dükkân, farklı etnik kimliklere sahip birçok kişinin yüz yüze iletişim kurabildiği, bir iletişim mekânı, bir buluşma yeridir. $\mathrm{Bu}$ anlamda belki de dünyada en çok farklı etnik kimliğe sahip bireyin yaşadığ Brooklyn'in bir mikro kozmosu olarak düşünülebilir. Öyle ki film boyunca Brooklyn'den çeşitli belgesel görüntülerde, röportajlarda ya da farklı milletlere mensup kişiler tarafindan Brooklyn ile ilgili verilen istatistiklerde hep bu çeşitlilik vurgulanmaktadır. Bütün bunlar göz önünde bulundurulduğunda, film Brooklyn'in bir çeşit yarı belgeseli olarak da düşünülebilir.

Fakat bir gün Vinny daha fazla para kazanmak adına dükkânı kapatıp, yerine bir vejetaryen lokantası açmaya karar verir. Bunun üzerine Auggie dükkânın kapanmaması için Vinny’i ikna etmeye çalışır. Çünkü dükkân farklı insanların, sadece sigara içenlerin değil, buradan yıllardır düzenli alış veriş yapanların ortak buluşma noktasıdır ve gittikçe dönüşüme uğrayan semtin görece iktidarın denetiminden uzak, kamusal bir diyalogun geliştiği, bozulmadan kalan ender mekânlarından biridir. Vinny, Auggie'nin çabaları, kendi Brooklynli geçmişinin ve kahramanlarının da katkılarıyla dükkânı kapatmaktan vazgeçer. Böylece Brooklyn Puro Şirketi ticari bir mekândan öte farklı milletlerden ve kesimlerden birçok insanın yaşamında büyük bir yer kaplayan, kendilerini özgürce ifade edebildikleri bir iletişim mekânı olarak tekrar eski günlerine geri dönmüştür.

Terry Eagleton’a $(2005,152)$ göre kültür sadece ona uygun yaşadığımız bir şey olmakla kalmayıp aynı zamanda büyük ölçüde uğruna yaşadığımız şeydir. Bu anlamda burada kültürel bir mozaikten bahsederken kendi yerel kültürleri doğrultusunda yaşayan farklı etnik kimliğe sahip insanların aynı zamanda bir arada yaşarken, her birinin onu muhafaza etmek uğruna fedakârlık gösterdiği bir kültür olgusundan bahsedilmektedir. Bu durum bir kentin sakinleri için, aynı zamanda onların o kentten beklentileri doğrultusunda oraya aidiyet sebebi olarak düşü- 
nülebilir de. Filmde Brooklyn böyle bir kent olarak sunulmuştur.

Filmde Brooklyn'deki farklı etnik kimliklere mensup kişilerin oluşturduğu kültürel bir mozaiğe daha çok vurgu yapmakla beraber özelinde ise bunu yansitan Brooklyn Puro Şirketi'nde geçen olaylar ele alınmıştır. Bu vurgu birçok sahne ile de desteklenmektedir.

Daha jenerikte bütün yazıların farklı renklerde olması, filmin işlediği bu temaya uygun düşmektedir. Yine film boyunca izleyiciye Brooklyn ile ilgili çeşitli istatistikler sunulmaktadır. Buna göre Brooklyn'de 2,3 milyon insan yaşamakta, 90'ın üzerinde farklı etnik grup ve 500 adet kilise, sinagog ve cami bulunmaktadır. Ayrıca işlenen suçlarla ilgili (hırsızlık, cinayet vb.) istatistikler, Brooklyn'de kaç tane çukur bulunduğu gibi istatistikler de mevcuttur. $\mathrm{Bu}$ istatistiklerin hepsinin farklı etnik gruplara mensup (Hintli, Uzakdoğulu, Latin vb.) bireyler tarafından sunulması da aynı zamanda Brooklyn'deki kültürel çeşitliliğe vurgu yapmaktadır.

Filmde bundan başka, farklı etnisitelere mensup çeşitli kişilerle yapılmış röportajlara yer verilmektedir. Örneğin, yaşlı bir siyahî adamla yapılan röportajda adam Brooklyn'i en büyük ve en modern şehir olarak tanımlar ve sonrasında da Brooklyn'in en sevdiği yönünün her milletten insanın olması olduğunu, en sevmediği yönünün ise bu insanların birbirleriyle geçinemiyor olması olduğunu belirtir. Bu anlamda da Brooklyn'de yaşamı devam ettirme ve çatışma unsurları iç içedir.

Film sırasında bazen belgesel görüntülere de yer verilmiştir. Bu görüntülerin birinde farklı ülkelerin mutfaklarına ait restoranlar dikkat çekmektedir: Hong Kong süper market, Polonya restoranı, Çin restoranı, Vietnam restoranı, Hindistan restoranı gibi. Brooklyn'de farklı milletlerden insanlar kendi kültürlerinin motiflerini de bu anlamda rahatça sergileyebilmektedirler.

Augie'nin dükkânındaki Kızılderili heykeli ise dikkat çekicidir ve farklı milletlerden insanların toplandığı dükkânda o da sanki bir birey gibidir (Amerika tarihinde yerlilere yapılan zulüm göz önünde bulundurulduğunda bu heykelin varlığı önemli bir göndermedir). Filmde Auggie'nin sevgilisi bir İspanyol iken (Violetta), Vinny'nin sevgilisi de siyahî bir kadındır (Dot). Dükkâna düzenli olarak girip çıkan kişilere odaklanıldığında yöresel kıyafetlerini giymiş olan Arap, Hintli, Siyahî ya da Uzakdoğulu kişileri görmek mümkündür.

Dükkânın müdavimlerine bakıldığında ise babası İtalyan, annesi ise Afrikalı Tommy Finelli, kara borsa bilet satıcısı Dennis, Porto Riko'lu bir adam ve düzenli aralıklarla dükkâna uğrayan (bazen saat satıcısı olarak, bazense Küba purosu satıcısı olarak), sürekli siyahî oluşuna sempatik bir şekilde vurgu yapan bir adamı ve bunlarla birlikte dükkânda çalışan, akıl sağlığı pek de yerinde olmayan Jimmy, dükkân ile ilgilenen Auggie ve patron Vinny görülmektedir. Bu insanların hepsi dükkânda iken bir sahnede Vinny gitar çalıp country tarzında bir şarkı söylemektedir. Siyahî adam ona “Hiç Brooklyn şarkısı biliyor musun?" diye sorduğunda Vinny İspanyolca bir şarkı söylemeye başlar. Bunun üzerine Finelli ve Siyahî adam da danslarıyla ona eşlik eder. Denilebilir ki modernizm bir Brooklynli adamın siyahî bir adam ona "Hiç Brooklyn şarkısı biliyor musun" diye sorduğunda İspanyolca bir şarkı çalıp söylemesi ve bu müzikte o siyahî adam ile kendisine İtalyan diyen başka bir siyahî adamın dans etmesidir.

Sürekli dükkânın önünde müzik yapan sokak müzisyenleri (siyah ve beyaz müzisyenlerden oluşmaktadır) ve yine dükkânın önünü mesken edinmiş evsiz bir deli filmde tasvir edilen modern ortamın sempatik karakterleridir.

Sonuç olarak Brooklynliler farklı etnik kimliklere tahammül edebilmekte, birbirleri ile kimi zaman geçinemeseler bile beraber, ortak bir yaşam alanını paylaşabilmektedirler. Marshall Berman özellikle 1970'lerden itibaren gelişen bu hususu modernistler açısından şöyle değerlendirmektedir: "Bugünün modernistleri, dünün modernistlerinin sıklıkla yaptı̆̆ gibi artık çağdaş 
olmak istiyorsak Yahudi, Siyah ya da Italyan ya da başka bir şey olmaktan vazgeçmemiz gerektiğinde ısrar etmez. Tüm toplumların bir şey ögrrendiği söylenebilirse, etnik kimliğin çă̆daş yaşamın açtığl ve herkese vaat ettiği benlik derinliği ve dopdoluluğu açısından özel bir önemi olduğunu ögrenmiştir" (Berman 2011, 443). Brooklyn'de yaşayan farklı etnik kimliklere mensup insanlar çağdaşlık adına kendi kimliklerinden vazgeçmek zorunda değildir. Aksi takdirde Brooklyn'deki bir modernizm olgusundan da bahsedilemezdi.

\section{Kentsel Aidiyetin Biçimi: Brooklynlilik Geleneği ve Taraftarlık Olgusu}

Film Lou Reed'in [film boyunca sıkça görülen 1942 yılında Brooklyn'de doğmuş efsanevi rock and roll müzisyeni. Özellikle 1960'larda Velvet Underground grubu ile üne kavuştu. Gruptan ayrıldıktan sonra solo kariyerine başarılı bir şekilde devam etti. 2013 yılında hayatını kaybetmiştir. Kaynak: http://www.biography.com/people/lou-reed-9453959] sözleriyle aç1lır. Lou Reed "Brooklyn'de yolumu bulabilirim, ama başka şehirlerde bulamam" diyerek aslında bir nevi Brooklyn'i evi olarak benimsediğini belirtmektedir ki modernizmin kendisinin de, (Berman'ın yaptığı tanımı göz önünde bulundurursak) aynı zamanda katı olan her şeyin buharlaşıp havaya karıştığı bir girdapta kendini evinde hissedebilmek olduğunu anımsamak gerekir. Filmde Lou Reed gibi, farklı etnik kimliklere mensup olan diğer insanlar da Brooklyn'de kendilerini evlerinde hissedebilmektedirler. Bu konuyu daha da açabilmek için "gelenek", "bireysel kimlik" ve "kolektif kimlik" kavramlarına ihtiyaç vardır.

Gelenek kavramı geçmişten aktarılan, devredilen bir şey olarak tanımlanabilir (Thompson 2004, 280). Mekanik modernleşme ise geleneği, eski olana bir atıf söz konusu olduğu için modernleşme karşıtı olarak görmektedir ve geleneğin varlığını da tehdit etmektedir. Thompson'a göre;

“1950'lerin ve 1960'ların modernleşme teorileri genellikle, 'geleneksel' ve 'modern' arasında genel bir karşıtlık varsaydı ve gerçek koşullar göz önüne alındiğında, gelenekten modernliğe geçişin tek yönlü toplumsal bir değişme süreci olduğunu kabul etti... Gelgelelim modernleşme süreci daha ileri bir safhaya geldiğinde önceki geleneklerin temeli giderek oyulmuştur: Modern toplumlar 'geleneksizleștirilmiştir"” (Thompson 2004, 273).

Yine Thompson bireysel kimlik ve kolektif kimlik tanımlarını da şöyle yapar:

"Kişisel kimlik, belirli karakterler ve potansiyellere sahip olan ve belirli yaşam yörüngesinde konumlanmış birey olma algısına gönderme yapar. Kolektif kimlik, bir kişinin toplumsal bir gruba ya da kolektiviteye üye olduğu duygusunu anlatır: Bir tarihi ve kolektif yazgisı olan toplumsal bir grubun parçası olma, ona aidiyet duyma hissidir" (Thompson 2004, 283).

Daha sonra da kimlik ile gelenek arasında bir ilişki kurar:

"Geçmişten aktarılan yargılar, inançlar ve davranışlar seti olarak gelenekler, bireysel ve kolektif düzeydeki kimlik oluşumunu oluşturacak sembolik materyallerin bir kismını temin eder. Benlik ve aidiyet - değişen derecelerde toplumsal bağlama bağll - geçmişten aktarlan değerler, inançlar ve davranış biçimleri tarafindan biçimlenir. Kimlik oluşum süreci asla sıfirdan başlamaz; daima, kimliğin zeminini oluşturan daha önceden var olan sembolik malzemeler üzerinde yükselir” (Thompson 2004, 284). 
$\mathrm{Bu}$ açıklamalar doğrultusunda, yerlisi ile göçebesiyle Brooklyn insanının, içinde konumlandığ gelenek tarif edilebilir. Mekanik modernleşme anlayışı 'modern toplumları' geleneksizleştirse de Brooklyn'de buna karşı direnen ve yeni bir gelenek inşasına girişen bir başka 'modern toplum' görülmektedir. Brooklyn'in yerlileri ile bulunduğu ülkeden Brooklyn'e göç etmiş bireyler eskiden sahip oldukları kolektif kimlikten fiziksel olarak uzak olmalarına ve önceki geleneklerinden bir ölçüde kopmalarına rağmen bireysel kimliklerini muhafaza ettikleri ve bununla birlikte daha üst bir kimlik anlayışını işaret eden, yeni bir kolektif kimlik anlayışı inşa etmişlerdir: Brooklynlilik...

Film boyunca çeşitli etnik gruplara mensup bireyler tarafından sıklıkla Brooklynlilik vurgusu yapılmaktadır. Bu vurgu, uluslaşma, Amerikan toplumuna aidiyet ya da Amerikalılık gibi kavramlara işaret etmekten çok kültürel bir kimliğe işaret etmektedir. Başka bir deyişle bireyler aynı zamanda, eski kimliklerine nazaran bir kaymanın gerçekleştiği bireysel kimliklerini sürdürmekle birlikte, bu bireysel kimliklerin tüm çeşitlilikleri ile zamanda ve mekânda var olabilmesine olanak tanıyan, çelişkileri, ortaklıkları, tahammülü ve bir çeşit kültürel peyzajı içinde barındıran yeni bir kolektif kültürü benimsemişlerdir (ki genelde farklı etnik grupları kendi yöresel kıyafetleriyle görürüz). Bu aynı zamanda yeni bir geleneğe sahip olma anlamına gelir: Brooklyn geleneği.

Harvey'in de belirttiği gibi şehir, çok çeşitli insanların "gönülsüzce ve agonistik bir biçimde de olsa" bir araya geldiği, değişken ve geçici bir ortak yaşamı oluşturdukları bir mekândır (Harvey 2013, 117). Demek ki bireyleri yaşadıkları şehre bağlı kılan her zaman ilksel bir aidiyet olmamaktadır. Yani bireylerin özellikle de göçmenlerin, o şehirde yerleşik olur olmaz o şehre kendilerini ait hissedebilmeleri her zaman beklenen bir durum olamamaktadır. Kişinin işinin, çocuğunun okulunun o şehirde olması, sürgün olması, başka bir şehirde yaşayabilecek ekonomik imkânlarının olmaması gibi sebepler de kişiyi o şehirde uzun bir süre yerleşik kılabilmektedir. Bu durum birbirinden çok farklı bireysel kimliklere sahip olan bireyler için geçerlidir ve Brooklyn'de doksan farklı etnik grubun yaşadığı düşünüldüğünde daha da somutlaşmaktadır. Yine şehir fiziksel ve idari bir takım değişiklikleri de içinde barındırırken, bir şehrin sakinleri sürekli değişiklik göstermekte, şehre yeni gelenler olmakla birlikte o şehirden ayrılanlar da sürekli bir geçicilik teşkil etmektedir. İşte Brooklyn sakinleri şehrin bu çelişkili ama bir yandan da müşterek yapısında kendilerini şehirlerine ait hissedebilmekte, yaşam alanlarının yok olmasına karşı kolektif bir kimlik oluşturabilmektedirler. Filmde taraftarlık olgusu bu bağlamda oldukça önemli bir yer tutmaktadır ve daha derin bir tartışma için taraftarlık olgusu incelenmelidir.

Brooklynlilerden öğrendiğimiz kadarıyla Brooklyn'de bir zamanlar büyük bir beyzbol takımı vardı: Brooklyn Dodgers. 1883 yılında Brooklyn Atlantics adıyla Brooklyn'de kurulan takım 1932'de Brooklyn Dodgers ismini almış, 1955 yılında Majör Lig'de şampiyonluğa ulaşmıştır. Takım 1958'de ise Kaliforniya'ya taşınmıştır ve böylece takımın ismi de Los Angeles Dodgers olmuştur. Takım Kaliforniya'ya götürülünce, sahası Ebbets Stadyumu da yıkılmıştır. 1957 yılında takımın başkanı Walter O'Malley, Ebbets stadyumunun yeni bir stadyum inşa ettirmek istemiş, bunun üzerine şehrin planlamacısı Robert Moses (Kendisinden, "Katı Olan Her Şey Buharlaşıyor" kitabında Marshall Berman da çok şikâyet etmektedir) ve belediye başkanı Robert Wagner Queens bölgesine yeni bir stadyum inşa edilmesini önermişler. Fakat Walter O'Malley, isteğinin kabul edilmemesi üzerine daha önce de belirtildiği gibi takımı 1958'de Kaliforniya'ya taşımıştır (www.sportsecyclopedia.com/nl/bdodgers/brooklyn). Filmden edindiğimiz bilgilere göre, Brooklyn'de yaşayanların neredeyse tamamı - hatta beyzbol ile ilgilenmediğini söyleyen Lou Reed bile - Dodgers takımı taraftarıydı. Bu durum ise kimlik ve 
gelenek inşasında önemli bir yere sahiptir.

Gündelik yaşamı organize eden ve gündelik yaşamın sıradan, rutin bir yanı olan taraftarlık, taraftar olunan şeyin takibini benliğin merkezi bir uğraşı haline getirir ve birisinin faaliyetinin ve başkalarıyla gerçekleştirildiği etkileşiminin önemli bir bölümünü yönetmeye hizmet eder. Taraftar olmak, benliğin ve gündelik faaliyetin düşünümsel örgütlenmesinde bir yoldur (Thompson 2004, 335). Bir anlamda taraftarlık, bireyin yaşam tarzında dönüştürücü bir rol oynar. Bireyin gönüllü olarak kendi faaliyetlerinin ve etkileşimlerinin yönetilmesini de kapsamakla birlikte birey aynı mekânda bulunmasa bile başka bireylerle de karşılıksız bir bağ kurar. $\mathrm{Bu}$ durum benliğin inşasında ve nihayetinde kolektif bir taraftarlık (kimlik) anlayışının kurulmasında önemli bir rol oynayarak başlangıcından itibaren sürekli daha sonraki zamanlara aktarılır, devredilir ve böylece taraftarlığın bir geleneği oluşturulmuş olunur.

Brooklynlilerin taraftarlık geleneği inşa edilirken tüm bunların yanında o zamana kadarki genel Amerikan geleneğinin içinde çok da yer almayan ve hatta buna aykırı bir durum söz konusudur: renk ayrımına meydan okuma. Takımları Dodgers'in en iyi oyuncusu olan (kimilerine göre gelmiş geçmiş en iyi oyuncu) Jackie Robinson [Amerikan Beyzbol Ligi Majör Lig'de 1889 'dan beri oynamış ilk siyahî beyzbolcu. Ligde, sporda yaklaşık 50 yıldan beri mevcut olan renk engelini kırmıştır. 1955'te Brooklyn Dodgers takımını şampiyonluğa taşıyan oyuncu, 42 numaralı formasıyla Amerika'da efsane olmuştur. Aynı zamanda Amerika'da siyahların uğradığı ırkçılığa karşı ve insan hakları mücadelesinde önemli bir rol oynamıştır. Kaynak: https://en.wikipedia.org/wiki/Jackie_Robinson]. Amerikan Beyzbol Ligi Majör Lig'de 1889 yılından beri oynamış ilk siyahî beyzbolcudur. Jackie Robinson Majör Lig'de renginden dolayı çok zor günler geçirmesine rağmen Brooklyn sakinleri ona her zaman sahip çıkmıştır ve hala da onları için bir kahramandır.

Filmdeki röportaj görüntülerden bir tanesinde eski bir Brooklyn Dodgers taraftarının söylediğine göre, takımın maçlarını oynadığı Ebbets Stadyumu küçük bir şehir kulübü gibiydi. Taraftarlar birbirlerini tanırlardı. Tüm oyuncular, hepsi Brooklynli olmasa bile Brooklyn'de otururlardı ve semtteki herkes onları tanırdı. Herkes aile gibiydi. Fakat artık Brooklyn'de beyzbol yoktur. Bu anlamda beyzbol ve Brookyln Dodgers taraftarlığı başlı başına kendi içinde bir gelenek olmakla birlikte Brooklynlilik geleneğine de içkindir, onun oluşmasında önemli katkılar sunmuştur. Fakat neticede Brooklyn sakinlerinin gündelik hayatlarının önemli bir kısmını kapsayan, benliklerinin oluşum süreci içerisinde önemli bir yere sahip beyzbol Brooklyn geleneğinin içinden çıkarılmış olsa da hala Brooklynliler takımlarını, stadyumu ve özellikle de Jackie Robinson'u unutmamışlardır. Mekanik modernleşme anlayışının bir sonucu olarak Ebbets stadyumunun yerine yeni site tipi apartmanlar yapılmıştır. Bir zamanlar beyzbol oynanan stadyumda yer alan şu tabela dikkat çekicidir: "Top oynamak, bisiklete binmek ve köpekle girmek yasaktır”. Stadyumun yıkım görüntülerinde yer alan eski Dodgers takımı oyuncularının da tüm Brooklynliler gibi üzgün oldukları görülmektedir, çünkü onlar da Brooklynlidirler, kendilerini bu kolektif kimlik ve gelenek içerisinde tanımlamaktadırlar.

Sonuç olarak stadyumun yıkılması Brooklyn sakinlerinin modernist karşılaşmalar yaptığı ve görece iktidarın denetiminden uzak, kamusal bir diyalog ortamı geliştirebildiği bir iletişim mekânının yıkılması demektir.

\section{Farklı Bireysel Kimliklerin Kamusal Bir Bulușma Noktası}

Daha önce de belirtildiği gibi Brooklyn Puro Şirketi, Brooklyn'in bir mikro kozmosu olarak işlev görmektedir. Bu mekânın içi ve dışı arasında kesin sınırlar bulunmamakta, mekân, bulunduğu sokağın bir uzantısı gibi durmaktadır. Brooklyn Puro Şirketi'nde hayat farklı etnik 
kimliklerin modernist karşılaşmaları, modern kamusal diyalogları ile devam ederken bir gün Vinny daha fazla para kazanmak adına dükkânı kapatıp yerine bir vejetaryen restoranı açmaya karar vererek bu ortamı, bu iletişim mekânını yok etme girişiminde bulunur. Vinny bu fikri yıllardır dükkânını idare eden Auggie'ye açtığında aralarında geçen konuşma şu şekildedir:

Vinny: Çok para. Geri çevirmek için deli olmalısın.

Auggie: 19 yll sonra buradan gidecek misin? Buna inanamiyorum.

Vinny: Burada dolarlardan bahsediyoruz. Bu dükkân yıllardır para kaybediyor. Bunu sen de biliyorsun.

Auggie: Ama sende para çok. Long Island'daki bütün o gayrimenkul anlaşmaları. Burayı vergi beyanında bile göstermiyorsun.

Vinny: Çok geç. Kontratı yaptık bile.

Auggie: Yani Brooklyn Puro Şirketi sağllklı ürünler dükkânı mı olacak?

Vinny: Zaman değişiyor Auggie. Tütün “out”, Buğday tohumu "in”. Bu senin için de iyi bir firsat olabilir. Belki sen de artık bir şeyler yapmalısın. Senin o tezgâhın arkasında yaşlı bir adama dönüşmeni izlemek istemiyorum.

Auggie: Herkes yaşlanır. Bunun nerede olduğunun ne önemi var.

\begin{abstract}
Auggie: Bu gerçekleşmeden iyice düşünmelisin Vincent. Tamam, burası çok önemli bir dükkân değil. Ama herkes buraya geliyor. Sadece sigara içenler değil. Ögrenciler şeker almaya geliyorlar. Bayan McKinna televizyon dergisi için geliyor. Deli Louie öksürük pastilleri için. Frank Diaz, El Diario için, Bay Chin çapraz bulmacası için. Bütün mahalleli buraya geliyor. Burası buluşma yeri. 12 yaşındaki çocuklar spor ayakkabısı için birbirlerini vuruyorlar. Burayı kaparsan tabuta bir çivi de sen çakmış olursun. Bu semtin ölmesine yardım etmiş olursun.
\end{abstract}

Bu konuşmadan aslında bu dükkânın sadece ticari bir amaç uğruna işletilmekten çıktığını, tüm Brooklyn sakinleri için bir buluşma yeri ve mekanik modernizmin tüm yıkıcılığına karşı direnmiş ve Brooklynlilerin kendilerini evinde hissedebildikleri kalan birkaç yerden bir tanesi olduğunu anlayabiliriz. Şehir ise hızla tek taraflı bir modernleşme, bir kentsel yenileme projesine maruz kalmıştır ve eskiye ait olan, geleneğin içinde barındırdığ 1 her şey bir bir yok olmaktadır. Auggie bu anlamda yeniye karşı eski olanı koruyarak modernist bir yaklaşım sergilemektedir.

Brooklyn Puro Şirketi'nin sahibi Vinny de eski bir fanatik Dodgers taraftarı ve herkes gibi Jackie Robinson hayranıdır. Dükkânı kapatacağını söyledikten sonra Auggie ile aralarında geçen konuşmanın sonunda üzüntülü bir şekilde dükkânda tek başına oturmaktadır. Kendi kendine "Brooklyn neden umurumda olacakmış ki? " diye söylenmektedir. Tam bu sırada içeriye üzerinde 42 numaralı forması ile Jackie Robinson'un hayaleti girer ve aralarında şu diyalog geçer:

Vinny: Jackie, Gelmiş geçmiş en iyi oyuncu. Çocukken senin için dua ederdim.

Jackie Robinson: Ben Amerika'yı değiştiren adamım Vinny. Bunu 
Brooklyn'de yaptım. Bana saldırdılar, lanetlediler! Hayatımı cehenneme çevirdiler. Onlarla savaşmama izin bile yoktu... Mağdur durumda olmak kötü Vinny. 53 yaşındayken öldüm. Senden daha gençtim. Ama iyi bir oyuncuydum değil mi?

Vinny: En iyisi Jackie. Sen en iyisiydin.

Jackie Robinson: Benden sonra her şey değissti. Sadece siyahlar için değil, beyazlar için de. Benden sonra siyahlar ve beyazlar birbirlerine eskisi gibi bakmadilar. Bunların hepsi burada, Brooklyn'de oldu.

Vinny: Sonra takımı buradan götürdüler. Bu kalbimi kırdı. Neden böyle aptalca bir şey yaptılar?

Jackie Robinson: Dolarlar söz konusuydu Vinny. Ebbets stadyumu artık yok ama orada yaşananlar hala aklımda. Önemli olan bu Vinny. Maddeye karşı zihin...

Ebbets stadyumunun yıkılması ile Vinny'nin dükkânı satması bu anlamda aynı temele dayanmaktadır: para (dolarlar söz konusu). Jackie Robinson işte Vinny'nin bunu anlamasını sağlar. Görüldüğü gibi; Dodgers takımı Kaliforniya'ya taşınmış, Ebbets stadyumu yıkılmış ve takımın yıldızı siyahî oyuncu Jackie Robinson ölmüş olmasına rağmen dükkânı kurtaran, Vinny’nin taraftarlığı üzerinden Brooklyn'e duyduğu bağlılığı hatırlamasıdır. Jackie Robinson Amerikan toplumundaki "beyaz oyuncu" algısının yıkılmasında çok önemli bir rol oynar ve Brooklyn sakinleri için bir semboldür. Onlar için bir oyuncu olmaktan öte Dodgers takımının ve Ebbets stadyumunun hatırasını canlı tutan, toplumun siyahîlere bakışını değiştiren bir figürdür, mekanik modernleşme anlayışının Brooklyn sakinlerinin ruhunu ele geçirmesinin önünde bir engeldir. Elbette ki Jackie, Vinny için de buna benzer şeyleri ifade etmektedir ve Vinny aslında takımı Kaliforniya'ya taşıyanların, stadyumu yıkanların, Jackie'nin hayatını cehenneme çevirenlerin tarafında olmak yerine Jackie'nin yanında, yani mekanik modernleşme anlayışının ve getirdiklerinin karşısında konumlanmıştır. Sonuç olarak biraz daha para kazanmak uğruna dükkânını kapatarak Brooklyn'in, mekanik modernleşmenin yıkıcılığına kurban gitmesinde katkısının olmasını istemez (tabuta bir çivi de kendisi çakmaz). Bu karar aslında Brooklynlilerin inşa ettikleri kolektif kimliğe kendileri de sahip olan Vinniy ve Auggie'nin kentsel dönüşümün yıkıcılığına karşı kazandığı bir zafer olmakla birlikte bu zaferde tüm Brooklynlilerin payı olduğu yadsinamaz.

Neticede Auggie, sevgilisinin 1srarlarına dayanamayarak Las Vegas'a giden Vinny'den aldığı "danslı ve şarkılı" telgraf sonunda dükkânın kapanmayacağını öğrenir. Bunun üzerine dükkânın önünde sevgilisi Violetta ile bir parti vermeye karar verir, bu partinin davetlileri bütün Brooklyn sakinleridir. Davetliler arasında transseksüeller, farklı milletten insanlar dikkat çekicidir. Parti 542 Brooklyn sakinini dükkân önünde buluşturmuş ve insanlar sokakta beraber dans etmiştir: modernizmin dansını. Brooklyn sakinleri kente aidiyetlerini sundukları gibi kentin uğrak mekânlarından birine de aidiyetlerini sunmuşlardır. Bu mekânın varlığı onların kendilerini Brooklyn'e ait hissetmelerinin nedenlerinden ve onların kentli kimliğini inşa eden unsurlardan sadece biridir.

$\mathrm{Bu}$ arada Auggie ve Violetta'nın bir bebekleri olmuştur. Çocuğun ismi “Jackie” (Jackie Robinson dükkânı kurtarmıştır), ilk katı gıdası ise filmde birçok konuşmaya konu olan, dükkân önündeki evsiz delinin yemek için insanlardan para istediği, Jackie Robinson'un da en sevdiği yiyeceklerden biri olan "Belçika Waffle"ıdır. Yani bebek Jackie, Brooklyn'i modern yapan, her ne kadar özünde farklı kültürlere, coğrafyalara ait olan, fakat aynı zamanda Brooklyn geleneği- 
nin inşasında yer alan şeylerin var ettiği bir bebektir: modernizmin bebeği.

Filmin sonu ise geneline çok uygun bir şekilde biter: Bir Porto Rikolu, bir siyahî, bir İtalyan-Afrikalı ve bir Brooklynli aynı şarkıyı dükkânda hep bir ağızdan söylemektedirler: Modernizmin Şarkısını...

\section{Sonuç}

Kentsel dönüşüm projeleri kentlerde giderek yaşam alanlarını sınırlandırmaktadır. Bununla beraber artık insanların, modernleşme adı altında dikilen devasa gökdelenleri, iş merkezlerini ve alışveriş merkezlerini alkışladıkları bir dönemden bahsetmek de mümkün. Kaba bir teknolojik belirlenimcilik anlayışı ile inşa edilen bu devasa yapıların aynalı camlarına bakan kalabalıklar onların büyüsüne kapılmaktan (Ayrıca bk. Ritzer 2011) da geri durmuyorlar. İçeriden bakanlarsa bu kalabalıkları görmüyorlar bile. Bu yapılarla birlikte, fabrikasyon mantığında her gün bir yenisi daha yapılan toplu konutlar, siteler ya da lüks rezidanslar, içinde yaşayan insanların tek mülkü olan gecekonduların yıkılmasını ve onların evsiz ve mülksüz kalmasını beraberinde getirirken aynı zamanda çevresel ve tarihsel bir takım faktörleri görmezden gelerek oldukça fazla sayıda iletişim mekânını yok etmekte, birçoğunu da tehdit etmektedir. Bu mekânlar Blue in the Face filminde olduğu gibi bir stadyum ya da herkesin uğrak noktası haline gelmiş bir dükkân olabilirken aynı zamanda çocukların oyun alanları, bir takım tarihi mekânlar ve mahalleler, tiyatro ve konser salonları da olabilmektedir.

İşte böyle bir durumda iken insanların yaşam alanlarına sahip çıkmaları, aynı zamanda bunu yaparken tüm farklı ulusal, dinsel, ahlaki vb. aidiyetlerinin üzerinde "ortak düşmana" yönelik kolektif bir kimlik geliştirebilmeleri önemlidir. Blue in the Face tam da bunun önemini hatırlatmaktadır. İnsanların tüm farklılıklarıyla bir arada yaşayabildiği, en azından yaşamaları gereken yaşam alanlarının giderek yok olmasına karşı yapılmış bir uyarı gibidir bu film. Aynı zamanda da bir kentin sakinlerinin, mekanik bir modernleşme anlayışının sonucu olan kentsel dönüşüm projelerine karşı nasıl bir kolektif kimlik oluşturabildiklerinin de sempatik bir örneğidir. Filmde bu kimliğin Brooklyn sakinleri ile birlikte göçmenlerin, siyahîlerin, transseksüellerin vb. kendilerini nasıl bir kente ait k1labildiği de görülebilmektedir. Filmdeki Brooklyn, farklılıklara gönülsüzce tahammül eden kişilerin oluşturduğu bir kent değil, bu farklılıkları içselleştirmiş ve aslında farklılıkları ortak bir Brooklyn geleneği ve Brooklynlilik kimliği altında ortadan kaldırmış sakinlere sahip olan bir kenttir. Farklılıkların bu şekilde ortadan kaldırılması kesinlikle bir tür asimilasyona işaret etmemektedir. Aksine farklılıklar fiili olarak ortadan kalkmamakta, beraber yaşamanın ve mücadele etmenin bir gereği olan kolektif bir kimliğin içinde her zaman muhafaza edilmektedir.

Elbette ki filmin 1995 yılında çekildiğini unutmamak gerekir. Aradan geçen yirmi yılı aşkın bir süre zarfinda kapitalizm etkisini arttırmış ve kentsel dönüşüm projeleri hız kazanmıştır. Bu durum düşünüldüğünde, Brooklyn'in aynı kaldığını, aynı kolektif kimliğe, aynı aidiyet biçimlerine sahip olduğunu söyleyebilmenin ne kadar mümkün olacağı tartışmalıdır. Bu anlamda şimdi çekilen bir Blue in the Face filmi büyük olasılıkla 1995 'tekinden daha farklı olacaktır. 


\section{KAYNAKÇA}

Berman M. (2011). Katı Olan Her Şey Buharlaşıyor. Çev. B. Peker \& Ü. Altuğ. İstanbul 2011. “Brooklyn Dodgers”. (n.d.). 18.02.2016 tarihinde şu kaynaktan alınmıştır: www.sportsecyclopedia.com/nl/bdodgers/brooklyn

Eagleton T. (2005). Kültür Yorumları. Çev. Özge Çelik. İstanbul 2005.

Harvey D. (2011). Umut Mekânları. Çev. Zeynep Gambetti. İstanbul 2011.

Harvey D. (2013). Asi Şehirler. Çev. Ayşe Deniz Temiz. İstanbul 2013.

“Jackie Robinson”. (n.d.) In Wikipedia. 17.02.2016 tarihinde şu kaynaktan alınmıştır: https://en.wikipedia.org/wiki/Jackie_Robinson

Kraucer S. (2011). Caligari'den Hitler'e Alman Sinemasının Psikolojik Tarihi. Çev. Ertan Y1lmaz. Ankara 2011.

Kraucer S. (2008). Kentin Gündelik Hayatı: Kameralı Adam. Ed. M. Öztürk, Sinematografik Kentler (2008) 43-68. İstanbul.

Lefebvre H. (2013). Kentsel Devrim. Çev. Selim Sezer. İstanbul 2013.

Lefebvre H. (2016). Şehir Hakkı. Çev. Iş1k Ergüden. İstanbul 2016.

“Lou Reed”. (n.d.). 20.02.2016 tarihinde şu kaynaktan alınmıştır: www.biography.com/people/ lou-reed-9453959

Ritzer G. (2011). Büyüsü Bozulmuş Dünyayı Büyülemek. Çev. Şen Süer Kaya. İstanbul 2011.

Sarup M. (2004). Post-Yapısalcılık ve Postmodernizm. Çev. Abdülbaki Güçlü. Ankara 2004.

Taş M. (1999). Avrupa'da Irkçılık Göçmenler ve Aşırı Să̆ Partiler. Ankara 1999.

Thompson J. B. (2004). Medya ve Modernite. Çev. Serdar Öztürk. İstanbul 2004.

Van der Loo H. \& van Reijen W. (2006). Modernleşmenin Paradoksları. Çev. Kadir Canatan. İstanbul 2006. 